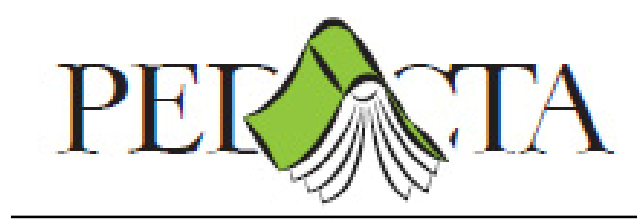

\title{
NEGYEDIK OSZTÁLYOS ORSZÁGOS KOMPETENCIAMÉRÉS KOVÁSZNA MEGYEI EREDMÉNYEI
}

\author{
THE 4TH GRADERS' NATIONAL COMPETENCE \\ MEASUREMENT RESULTS IN KOVASZNA COUNTY
}

\author{
Barabás Andrea
}

\begin{abstract}
From the 2012-2013 school year the Romanian educational reform put a high emphasis on the development of skills and competencies. The preparatory class has been introduced in the primary as well as a national mathematical, reading comprehension and text writing competency testing was started. The national surveys are not accompanied by a background questionnaire. In our research we put emphasis on the analysis of the factors which influenced the results of the 4th graders. During the research we used our background questionarries. According to the outcomes of these questionnaries and the Hungarian minority 4th graders' competence measurement results from Covasna county (N=1054), we have created our database (KOV-ET-OM-2017). In our research we deal with the following questions: Are those pupils who have attended preparatory class more efficient in these testings than those who haven't? Does the parents' educational background influence in the same level the pupils' Mathematical, Romanian and Mother tongue competencies? The results reveal the fact that those students who have attended preparatory class have higher results in these competency testings than those who haven't. Moreove we could also conclude that the education of the parents does not influence in such level the children's skills and competencies.
\end{abstract}

Keywords: preparatory class, competency testing, primary school, school performance

\section{Bevezetés}

Románia a 2011-es Oktatási törvény 68. paragrafusában rögzíti azt az intézkedést, amely szerint a nyolc alapkompetencia1 kialakítása kerül az oktatási rendszer fókuszába. Nagyobb figyelem fordul az oktatás kezdő szakasza felé, ahol azoknak a készségeknek, képességeknek a kialakítása történik, amelyek a későbbi önálló tanuláshoz nélkülözhetetlenek. Az előkészítő osztály és az integrált tevékenységeken alapuló oktatás célja, hogy a gyerekek számára zökkenőmentesebbé tegye az iskolába való beilleszkedést, valamint sikerélményekhez juttassa a tanulókat. Az integrált tantárgyakon alalpuló oktatás "a hagyományos diszciplináris megközelítéstôl eltér, és valamilyen egységes alapot teremt a vizsgált objektum, adott esetben a természet megismeréséhez és értelmezéséhez" (Chrappán, 1998, 6).

A 2011-es Oktatási törvény életbelépésével nemcsak a bemeneti szabályozásban történt változás, hanem a kimeneti rendszer is megújult. A szövegértési és matematikai kompetenciák felmérése érdekében a 2013/2014-es tanévtől kezdődően a román Oktatási Minisztérium fennhatósága alá a 2., 4 . és 6. osztályos tanulók román nyelvü olvasás és szövegértés, valamint matematika és természettudományok

\footnotetext{
${ }^{1}$ az anyanyelvi kommunikáció; idegen nyelvű kommunikáció; matematikai, természetudományi és technológiai kompetenciák; digitális kompetenciák, a tanulás tanulása; szociális és állampolgári kompetenciák; kezdeményezőképesség és vállalkozói kompetencia; kulturális kifejezőkészség.
} 
területén kell bizonyítsák tudásukat (kisebbségi oktatásban tanulók számára az anyanyelvi olvasás és szövegértés is felmérésre kerül). A kisebbségi oktatás "az általános ismeretek és kompetenciák átadásán kívül rejtett tantervként a kisebbségi identitást a maga kapcsolatrendszerével és világról alkotott képzeteivel együtt újratermeli” (Papp Z., 2012, 10). Érdemes vizsgálni, hogy a kisebbséghez tartozás mint a szocioökonómiai háttér egyik összetevője - segíti vagy esetleg gátolja az iskolai eredményességet? (Kozma, 2003). A romániai kisebbségi oktatás a román oktatási rendszer részét képezi, azonban rendelkezik bizonyos sajátosságokkal, amelyek a tantervekben, tananyagokban, vizsgarendszerben megmutatkozik a magyarság számarányából, társadalmi-politikai helyzetéből kifolyólag (Fóris-Ferenczi, 2007, 45).

\section{Bemeneti és kimeneti szabályozás}

A romániai oktatásszabályozási mechanizmusokra a bemeneti-kimeneti szabályozás jellemzö: a bemenetet a tanterv, a kimenetet a vizsgakövetelmények szabályozzák. A kerettanterv az elemi oktatásban tartalmazza a közös, kötelező törzsanyag óraszámát és megengedi olyan választható tárgyak bevezetését a helyi tanterv részeként, melyek nemcsak önálló, hanem müveltségterületen belüli (integrált), illetve müveltségterületen átívelö (transzdiszciplináris) tantárgyak is lehetnek (Potolea és Manolescu, 2006; Fóris-Ferenczi, 2008; Kádár, 2016). Ennek legfőbb célja az volt, hogy lehetőséget biztosítson a korábbiaknál életszerübb és változatosabb tantárgyi struktúra kialakítására. A választható tantárgy a különböző opcionális tantárgyak/témák, azaz választható tevékenységek beiktatását feltételezi, amelyeket az iskola/a pedagógus ajánl vagy választ a központilag javasolt opcionális tantárgyak közül. Ennek a kiválasztásakor/kidolgozásakor az iskolának figyelembe kell vennie a tanulók érdeklődési körét, az iskola anyagi és humán erőforrásait, az iskola sajátos helyzetét, a helyi közösség igényeit és szükségleteit (Potolea és Manolescu, 2006; Fóris-Ferenczi, 2008; Péter, 2012). A jelenlegi rendelkezések szerint az elemi osztályokban a választható tantárgyakra fordítható órakeret heti 1 óra. Viszont a kisebbségi oktatásban résztvevő tanulók túlzott iskolai terhelése miatt a pedagógusok többsége magyar tagozaton általában nem iktat be választható tantárgyat.2

A romániai alaptanterv az oktatási szakaszok végére meghatározott követelményeket ír elö: különböző tantárgyakban adott évfolyam végén milyen tudással kell(ene) rendelkeznie a tanulónak. A romániai alaptantervben a követelményrendszer szerkezete az életkori jellemzőkre figyelő fejlesztési, képzési szakaszokra, ún. curriculáris szakaszokra épül a következőképpen:

- alapképességek kialakítása (előkészítő, az 1. és 2. osztály);

- fejlesztés (3-6. osztály);

- pályaorientáció (7-9. osztály);

- elmélyítés (10-11. osztály);

- szakosodás (12-13. osztály).

A curriculáris szakaszok szintjei nem esnek egybe az oktatási szakaszokkal (Fóris-Ferenczi, 2008, 43).

1.táblázat: Az oktatási szakaszok és curriculáris szakaszok a romániai közoktatásban (saját szerkesztés)

\begin{tabular}{|l|l|l|l|}
\hline Életkor & Osztály & ISCED & Curriculáris szakaszok \\
\hline 19 & XIII. & \multirow{2}{*}{ ISCED3 } & szakosodás \\
\hline 18 & XII. & & \\
\cline { 1 - 1 } 17 & XI. & & elmélyítés \\
\hline 16 & X. & pályaorientáció \\
\hline 15 & IX. & ISCED2 & \\
\hline 14 & VIII. & & \\
\hline 13 & VII. & &
\end{tabular}

\footnotetext{
${ }^{2}$ Előkészítő osztályban a román tagozaton járó gyerek minimális óraszáma 19, maximális óraszáma 20, a magyar anyanyelven tanuló gyerek számára a minimális óraszáma 22, maximális óraszáma 23, míg negyedik osztályban a román tagozaton járó gyerek minimális óraszáma 21, maximális óraszáma 22, a magyar anyanyelven tanuló gyerek számára a minimális óraszáma 25, maximális óraszáma 26.
} 


\begin{tabular}{|l|l|l|l|}
12 & VI. & & fejlesztés \\
\hline 11 & V. & \multirow{2}{*}{ ISCED1 } & \\
\hline 10 & IV. & & \\
\hline 9 & III. & & alapképességek kialakítása \\
\hline 8 & II. & & \\
\hline 7 & I. & & \\
\hline 6 & Elökészítő & & \\
\hline
\end{tabular}

Az Oktatási törvény által elöírt mérések országos szinten egységes tételek alapján történnek. Az interdiszciplináris, a diákok információ-felhasználási és összefüggés-keresési készségeire fókuszáló feladatsor eredményeiről országos összefoglaló jelentés készül, mely az oktatási reform irányát hivatott megszabni.

\section{Kompetenciamérések az alapképességek kialakításának szakaszában és a fejlesztési szakaszban}

A 2013/2014-es tanévtől kezdve az romániai Oktatási törvénynek megfelelően országos komptenciamérésekre kerül sor 2., 4. és 6. osztály végén. Második osztályban román és anyanyelven írásból, olvasásból és matematikából tesztelik a tanulókat. A kisebbséghez tartozó diákok a negyedik osztály végén román nyelvü írott szöveg megértéséről és az írásbeli kifejezőképesség kompetenciáiról, a matematikai kompetenciákról, az anyanyelvi írott szöveg megértéséröl adnak számot. A hatodik osztályos mérések során a matematikai és természettudományos kompetenciák, valamint a kisebbségi oktatásban az anyanyelvi kompetenciák kerülnek felmérésre. Az országos felmérések egységes tételek alapján történnek és minden oktatási intézmény köteles az Oktatási Minisztérium által kidolgozott módszertan alapján megszervezni. Nem a tantervi tartalmak elsajátítását mérik, hanem azt, hogy milyen mértékben tudják alkalmazni a tanultakat a mindennapi életben felmerülő problémák megoldásában.

A 4. osztály végén voltak már mérések korábban is (1995-ben, 1998-ban, 2000-ben, 2005-ben, 2007ben és 2009-ben), de 2. és 6. osztályban a 2013/2014-es tanévben került sor először országos mérésre3. A második és hatodik osztály végén történő országos mérés az egyéni fejlesztésre irányul, a pedagógus az eredményeket egyénre szabott fejlesztési tervek kidolgozására használhatja. A méréseket az Oktatási törvény és "A 2., 4. és 6. osztály végén történő országos mérések szervezési és lebonyolítási módszertana" szabályozza. Az újszerü országos mérések bevezetésének egyik oka az volt, hogy a pedagógusok értékelését megbízhatatlannak tartották. A centralizált, központi szinten kidolgozott új mérések arra irányulnak, hogy segítsék a tanárokat az azonos szabványokon alapuló felmérésében, és egyúttal megbízhatóbb mérési mechanizmusokat biztosítsanak az egyéni tanuláshoz.

A felmérő tesztek a nemzetközi PISA-típusú mérések mintáját követik (Kitchen et al., 2017). A 2011/1. Oktatási törvény, 74. fejezet, 3. cikkelye szerint a negyedik osztály végén az Oktatási Minisztérium mintavételi eljárással országos szinten méri az elemi tagozaton elsajátított alapkompetenciákat. Az Oktatási törvény által elöírt, újszerủ mérések szerint az országos kompetenciamérések általános célja a tanulók, pedagógusok, szülők, nevelési tanácsadók, igazgatók, szakfelügyelök számára olyan információk szolgáltatása, amelyek segíthetik őket a tanítási-tanulási folyamat optimizálásában (Szántó, 2015). Habár a negyedik osztály végén történő mérésnek az Oktatási törvény szerint az elemi oktatás (ISCED 1) diagnosztizálása a cél, az eredmények össszehasonlítási alapként csak a feladatok szintjén hasznosíthatóak. Nem derül ki, hogy a tanuló hogyan viszonyul az iskolai, megyei vagy országos átlaghoz, az iskolák eredményei sem hasonlíthatóak össze. A tanulói eredményességet befolyásoló családi háttér befolyásoló hatásával számos kutatás foglalkozik (Bourdieu, 1999; Andor és Liskó, 2000; Pusztai, 2004, 2009), viszont a romániai országos kompetenciaméréseket nem kíséri olyan háttérkérdőív, ami a befolyásoló háttértényezőkről információt biztosítana (Kitchen et al., 2017). A tanulói háttérkérdőív vizsgálata fontos részét képezheti az adatok elemzésének, mivel ezek alapján lehet vizsgálni, hogy a tanulók a szocioökonómiai háttér szerint elvárható eredményhez viszonyítva jobban vagy rosszabbul teljesítenek. Az iskolai légkör, a pedagógusok jellemzői, az iskola tanulási környezete

\footnotetext{
${ }^{3}$ Országos Értékelő és Vizsgaközpont (CNEE) (2017): Országos jelentés- Az elemi oktatásban elsajátított alapkompetenciák értékelése negyedik osztály végén. (Raport National -Evaluarea competenţelor fundamentale dobândite în ciclul primar la finalul clasei a IV-a 2017)
} 
is meghatározza a tanulók teljesítményét a családi-társadalmi háttér mellett (Pusztai, 2009; Bacskai, 2007, 2015; Széll, 2015; Fehérvári, 2016), az intézményi és tanári háttérkérdöív nagymértékben hozzájárulhat az eredmények árnyaltabb értelmezéséhez.

Az értékelési kódok alapján a feladat megoldása lehet: teljesen jó megoldás, részben jó megoldás, hibásan elvégezve vagy pedig nincs megoldva. Az értékelés a feladatok szintjén történik. Ez a mikroszinten történő visszacsatolás az individumra irányuló értékelést szolgálja, a diák fejlesztésére irányul, a hibás vagy nem megoldott feladatok típusa és mennyisége szerint egyéni tanulási tervek kidolgozására kellene használni. Előnyös, hiszen motiváló lehet a tanuló számára, mivel személyre szabott értékelést kap. Viszont kevés informativitással rendelkezik, nem lehet meghatározni, hogy a diák a többiekhez képest hogyan teljesít (Buda, 2011).

Az iskolai munka folyamatos fejlesztésében, megújításában kulcsszerepet tölthetne be a mezoszintü visszacsatolás. A diagnosztikus mérés-értékelés az iskolai szintü kiértékelés után a tantárgyi tanítástanulás, a képességfejlesztés szabályozásában, a tennivalók tervezésében hatékonyan segíthetné a pedagógusok munkáját (Báthory, 2002).

A felmérés eredményeiről iskolai, valamint megyeszintű jelentés készül, amelyek az országos jelentés elkészítését segítik. A makroszinten nyert információkat elsősorban az oktatáspolitikusok és a kutatók használják fel, diagnózisra, döntéselőkészítésre. Ez a visszacsatolás egy nagyon lassú folyamata, mivel a rendszer egészét érinti (Buda, 2011). A kisebbségi oktatásban résztvevő tanulók eredményeiről nagyon kevés információt szerezhetünk. Az országos jelentések nem tartalmaznak a kisebbségi oktatásban résztvevők mérési eredményeire vonatkozó adatokat. A 2017-es országos jelentésben a kiegészítő melléklet táblázatai sem nyújtanak semmiféle információt a tanulók anyanyelvi szövegértésének eredményeiröl.

\section{A kutatás bemutatása. Kutatási kérdések, hipotézisek. Adatok és módszerek}

Kutatásunkban arra vállalkoztunk, hogy bemutatjuk a romániai oktatási rendszer alsó tagozatán történő országos mérés Kovászna megyei eredményeit, valamint megpróbáljuk feltérképezni az eredmények hátterében meghúzódó befolyásoló tényezőket. Alapvető kutatási kérdésünk, hogy a negyedik osztályos kompetenciamérések eredményeit milyen tényezők befolyásolják? Kíváncsiak voltunk arra, hogy többen értek-e el átlag feletti eredményeket azok a tanulók közül, akik előkészítő osztályt jártak, mint akik nem jártak előkészítőbe? A szülők iskolai végzettsége azonos mértékben befolyásolja-e a különböző kompetenciaterületek mérési eredményeit?

A szakirodalomra alapozva a következö hipotéziseket fogalmaztuk meg:

1. Feltételezzük, hogy azok a tanulók, akik előkészítő osztályban jártak, nagyobb arányban érnek el átlag feletti eredményeket a felméréseken. Az előkészítő hosszabb átmenetet biztosít az óvoda és az iskola között, több időt hagyva az iskola teljesítményorientált munkamódjához való hozzászokásra. A korai iskolakezdés pozitív hatása föleg a hátrányos helyzetü gyerekek fejlödésében követhetö nyomon. Az elökészítő osztály iskolai kudarccsökkentő hatása a további iskolai sikerek elérését alapozza meg. Azok iskolakezdés előtti/korai iskolai tevékenységek, amelyek stimulálják a gyerek érdeklődését és fejlesztik a képességeit, nagymértékben befolyásolják a későbbi iskolai eredményeket (Mihály, 2001; Melhuish et al., 2008; Barabás, 2019).

2. Feltételezzük azt, hogy az anyák iskolai végzettségének jelentősebb hatása van a tanulók kompetenciaméréseinek eredményeire. A tanulók iskolai teljesítménye és a szülők iskolai végzettsége között erős összefüggések mutathatóak ki (Bourdieu, 1999; Bradly és Corwyn, 2002). A családok társadalmi státusát meghatározó tényezők közül a szülők iskolai végzettségének van leginkább meghatározó szerepe. Az apa iskolázottsági szintjének erős a befolyásoló hatása a következő generáció iskolai eredményességére nézve, az anyák iskolai végzettsége azonban a fiatalabb generációknál sok esetben magasabb, mint az apáké (Pusztai, 2004). Magyarországon nagyon magas a teszteredmények korrelációja az anya iskolai végzettségével (Róbert, 2004).

Kutatásunk feltáró jellegü, 1054 negyedikes diák 2016-17-es tanév végén sorra kerülő országos kompetenciaméréseinek eredményeit mutatjuk be. Kutatásunk segíti, hogy betekintést nyerjünk a kisebbségi magyar tanulók eredményeiről és a befolyásoló tényezőkről a megyei szintü teljeskörü 
adatfelvételnek köszönhetően. Hivatalos adat nincs a megyei jelentésben a magyarul tanulók számáról, a tanítók adatbázisa alapján a 2016-17-es tanévben 1400 negyedikes gyerek kezdte el a negyedik osztály. Nincs információnk arról, hogy tanév közben történt-e iskolaelhagyás, elvándorlás, stb., mert erről a jelentések csak román nyelven tanuló diákokkal összesített adatokat tartalmaznak.

A kompetenciamérések eredményeit befolyásoló tényezők felderítése érdekében saját készítésü háttérkérdőívet alkalmaztunk. A kérdőív a tanuló iskolai életére, tanulmányi helyzetére, a tanórán kívüli foglalkozások, olvasási szokások felmérésére, valamint a családi háttérjellemzők feltárására vonatkozó kérdéseket tartalmaz. A tanulók eredményességét, valamint a befolyásoló tényezők elemzését a kérdőív és a mérési eredmények alapján létrehozott saját készítésủ adatbázis (KOV-ET-OM-2017 adatbázis4) tette lehetővé.

A felmérés és a háttérkérdőív kitöltése a tanév végén, 2017 május utolsó hetében történt. Az országos mérések során a tanulók matematikából 20 feladatot tartalmazó tesztet, magyar és román nyelv felmérésére pedig 15-15 feladatot tartalmazó tesztet kellett megoldaniuk. Az országos mérések eredményeinek kiértékelése kódok alapján történt, és a feladatok szintjén történő értékelésre irányul. Tanulmányunkban nem a feladatok szintjén szeretnénk értékelni a tanulók teljesítményét, hanem az eredményeket befolyásoló tényezőket vizsgáljuk. A kódok mellé pontértékeket rendeltünk, hogy az eredmények statisztikai elemzését lehetővé tegyük. Mindhárom mérési területen négy kategóriát határoztunk meg a diákok tanulmányi minősítéseivel összhangban: elégtelen, elégséges, jó, nagyon jó.

2. táblázat: A kódok mellé rendelt pontértékek

\begin{tabular}{lll}
\hline Kód & A kód jelentése & Kód mellé rendelt pontérték \\
\hline 10 & Teljesen helyes válasz & 4 \\
\hline 11 & Részben helyes (3 helyes válasz) & 3 \\
\hline 12 & Részben helyes (2 helyes válasz) & 2 \\
\hline 13 & Részben helyes (1 helyes válasz) & 1 \\
\hline 79 & Helytelen válasz & 0 \\
\hline 99 & Hiányzó válasz & 0 \\
\hline
\end{tabular}

\section{Eredmények}

A matematika felmérés eredményeit vizsgálva megállapíthajuk hogy a tanulók (N=1012) 29.7\%-a nagyon jó, 50.9\%-a jó eredményeket ért el a 20 feladatot tartalmazó teszt megoldása során. A vizsgált minta ötöde nagyon gyenge eredményeket ért el: $9.8 \%$-a az elégséges, $9.5 \%$-a pedig elégtelen kategóriába került. A román nyelvi kompetenciák felmérésére szolgáló feladatsorok megoldása során a

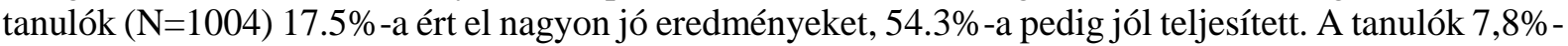
a elégtelen és 20,4\%-a elégséges eredményeket ért el.

A magyar anyanyelvü diákok román nyelvi kompetenciáját mérő feladatlap nemcsak a lehetséges nyelvi korlátok miatt nehéz, hanem a szöveg terjedelme, valamint az egyes feladatok megválaszolásához elvárt bonyolult társítási müveletek miatt is (Kádár, 2016). A mérési eredmények rámutatnak arra, hogy anyanyelvből a vizsgált tanulók ( $\mathrm{N}=990)$ 51.6\%-a nagyon jó és $42.7 \%$-a jó eredményeket ért el. Elégtelen mindössze a tanulók 2\%-a, elégséges 3.7\%-a, így a gyengén teljesítők alig haladják meg az 5\%-ot. Az eredmények rávilágítanak arra, hogy az anyanyelven történő szövegolvasás és értelmezés terén a vizsgált tanulók nagy többsége jól és nagyon jól teljesít. Ez fontos a tanulók további iskolai teljesítménye szempontjából, hiszen kutatások igazolják, hogy azok a diákok, akik az általános iskola alsó tagozatán alacsony színvonalú olvasási képességgel rendelkeznek, valamint a szövegértelmezés terén gyengén teljesítenek, azok az általános iskola felső tagozatán már nem tudnak felzárkózni (Pletl, 2012).

\footnotetext{
${ }^{4}$ Saját készítésủ adatbázis: az elemi tagozat végén sorra kerülő országos kompetenciamérés Kovászna megyei adatbázisa
} 
3. táblázat: Kompetenciamérések eredményei

\begin{tabular}{llll} 
& Magyar & Matematika & Román \\
\hline Elégtelen & $2,0 \%$ & $9,5 \%$ & $7,8 \%$ \\
\hline Elégséges & $3,7 \%$ & $9,8 \%$ & $20,4 \%$ \\
\hline Jó & $42,7 \%$ & $50,9 \%$ & $54,3 \%$ \\
\hline Nagyon jó & $51,6 \%$ & $29,7 \%$ & $17,5 \%$ \\
\hline
\end{tabular}

Forrás: KOV-ET-OM-2017 adatbázis

1. Kutatásunkban azt tüztük ki célul, hogy megvizsgáljuk az előkészítő osztály és kompetenciaméréseken elért eredmények közti összefüggéseket. Arra kerestük a választ, hogy kimutatható-e az előkészítő osztálynak tulajdonítható eredményesség-növekedés a vizsgált mintában? Kutatások támasztják alá, hogy a hátrányos helyzetü, nyelvi készségeikben elmaradt gyerekek iskolai életbe való beilleszkedésének megkönnyítése, az iskolai kudarcok csökkentése érdekében több országban is eredményesnek tünik a korai iskolakezdés (Mihály, 2001). Az esélyteremtés, hátránykompenzációt támogató integrált oktatás a gyermekek szociokulturális környezetéből eredő hátrányaik csökkentését szolgálják (Darvas et al., 2015). Alátámasztott az is, hogy iskolaelőkészítőben vagy iskolai életet megelőző szakaszában azok a tevékenységek, amelyek a gyerek érdeklődését felkeltik és képességeit fejlesztik, megalapozzák a későbbi sikeres iskolai teljesítményt (Melhuish et al., 2008). A Kovászna megyei pedagógusok is hasonló véleményen vannak: nagy többsége sikeres oktatáspolitikai döntésnek ítéli meg az előkészítő osztály bevezetését. Az előkészítő osztályban az integrált tevékenységek kompetenciafejlesztő hatásuk révén segítik, hogy az óvoda-iskola átmenet zökkenőmentesebbé váljon és a hátrányos helyzetü gyerekek felzárkóztatása is sikeresen kivitelezhető (Barabás, 2019).

A vizsgálatban résztvevő tanulók 88\%-a járt előkészítő osztályban. A kompetenciamérések eredményeit átkódoltuk, két kategóriát határoztunk meg: átlag alatti és átlag feletti eredményeket vettük alapul mindhárom mérési területen.

Erős szignifikáns összefüggést fedezhetünk fel $(\mathrm{p}=0,000)$ az előkészítő osztály és a román kompetenciamérés eredményei között. Átlag fölötti eredményeket 48,3\%-a ért el azoknak, akik előkészítőt jártak, míg 28,3\%-a került az átlag fölötti kategóriába azok közül, akik nem jártak elökészítő osztályt. Az elökészítő osztály és a matematika mérési eredmények között is szignifikáns $(\mathrm{p}=0,000)$ összefüggést találtunk. Akik előkészítő osztályban jártak, azok közül 57,7\%-a kerül az átlag feletti csoportba, míg akik nem jártak, azok közül 28,7\%-a ér el átlagon felüli eredményeket. Azok a gyerekek, akik előkészítőbe jártak, sokkal nagyobb eséllyel kerülnek az átlag feletti kategóriába, mint azok, akik nem jártak. Az előkészítő osztály és a magyar kompetenciamérések eredményei között is erős szignifikáns összefüggés $(\mathrm{p}=0,000)$ mutatható ki. Eredményeink összhangban vannak 40 országban készült PIRLS vizsgálat eredményeivel, amelyek igazolják, hogy a korai életkorban intézményes oktatási formákban való részvétel és a 4. évfolyamon nyújtott szövegértés-teljesítmény között általában minden országban pozitív összefüggés található (Mullis et al., 2007).

4. táblázat. Az előkészítő osztály és a kompetenciamérések eredménye közti összefüggések

\begin{tabular}{|c|c|c|c|c|c|c|}
\hline & Matematik: & & Román & & Magyar & \\
\hline & átlag alatti & átlag fölötti & átlag alatti & átlag fölötti & átlag alatti & átlag fölötti \\
\hline $\begin{array}{l}\text { Járt előkészítő } \\
\text { osztályt }\end{array}$ & $42.30 \%$ & $57.70 \%$ & $51.70 \%$ & $48.30 \%$ & $37.90 \%$ & $62.10 \%$ \\
\hline $\begin{array}{l}\text { Nem járt előkészítő } \\
\text { osztályt }\end{array}$ & $71.30 \%$ & $28.70 \%$ & $71.70 \%$ & $28.30 \%$ & $69.20 \%$ & $30.80 \%$ \\
\hline
\end{tabular}

Nmatematika:1004, $\mathrm{P}=0,000$, adj. resid $>5$ Nromán:994, $\mathrm{P}=0,000$, adj. resid $>3$ Nmagyar:980, $\mathrm{P}=0,000$, adj. resid $>6$ (A táblázatban aláhúzással jelöltük azoknak a celláknak az adatait, ahová a véletlenszerü eloszlásnál többen kerültek.) 
2. Kutatásunkban vizsgáljuk, hogy az apa vagy az anya iskolai végzettsége van erősebb hatással a kompetenciamérések eredményeire? A szülők iskolai végzettségében hét kategóriát különböztettünk meg: nem járt iskolába, 1-4 osztály, 5-8 osztály, 9-11 osztály, 12 osztály érettségi nélkül, 12 osztály érettségivel, felsőfokú végzettség.

5. táblázat: Szülők legmagasabb iskolai végzettsége

\begin{tabular}{lll}
\hline Iskolai végzettség & Apa & Anya \\
\hline Nem járt iskolába & $3.5 \%$ & $3.4 \%$ \\
\hline $1-4$ osztály & $7.0 \%$ & $7.8 \%$ \\
\hline $5-8$ osztály & $16.7 \%$ & $17.1 \%$ \\
\hline 9-11 osztály & $25.0 \%$ & $20.8 \%$ \\
\hline 12 osztály érettségi nélkül & $12.2 \%$ & $7.1 \%$ \\
\hline 12 osztály érettségivel & $21.2 \%$ & $23.5 \%$ \\
\hline Felsőfokú végzettség & $14.5 \%$ & $20.2 \%$ \\
\hline
\end{tabular}

Forrás: KOV-ET-OM-2017 adatbázis

A szülök végzettségét átkódoltuk, 3 kategóriát alkottunk: általános iskolai végzettség, középiskolai végzettség, valamint felsőfokú végzettség. Az eredmények alapján megállapíthatjuk, hogy az általános iskolai végzettséggel rendelkező szülők aránya hasonló: az anyák 28,4\%-a, az apák 27,1\%-a rendelkezik általános iskolai végzettséggel. A középiskolai végzettséget tekintve az apák aránya magasabb: az anyák 51,4\%-a, az apák 58,4\%-a rendelkezik középfokú végzettséggel. Az anyák 20,2\%-a, míg az apák 14,5\%a rendelkezik felsőfokú végzettséggel.

Szignifikáns összefüggés $(\mathrm{p}=0,000)$ mutatható ki a szülők iskolai végzettsége és a tanulók mérési eredményei között mindhárom kompetencia területen. A korábbi kutatások az anya iskolai végzettségének a meghatározó szerepét mutatták ki. Az iskolai eredmények szorosabb kapcsolatban voltak az anya iskolázottságával, mint az apáéval (Csapó, 1998). Az általános iskolai végzettsége és az anyanyelvi felmérés eredményei közötti összefüggések vizsgálata során megállapíthatjuk, hogy nincs számottevő eltérés a szülők végzettsége és az átlag feletti eredmények között. Nagyon erös hatása van viszont az átlag alatti kategóriára az anyák általános iskolai végzettségének (Sig.***, Adj. Resid=10).

Az anyanyelvi felmérési eredmények vizsgálata során a középfokú végzettséggel rendelkező apák meghatározóbb szerepére derült fény: több tanuló kerül az átlag feletti kategóriába, mint a középfokú végzettséggel rendelkező anyák esetében. Lényegesen erősebb a felsőfokú végzettséggel rendelkező anyák és az anyanyelvi mérési eredmények közti összefüggés: nagyobb arányban érnek el átlagon felüli eredményeket a felsőfokú végzettséggel rendelkező anyák gyerekei, mint a felsőfokú végzettséggel rendelkező apák esetében.

A szülök iskolai végzettsége és a román kompetenciamérés eredményei közti összefüggéseket vizsgálva megállapíthatjuk, hogy a középfokú végzettséggel rendelkező anyák és apák esetében nincs számottevő eltérés. Az általános és a felsőfokú végzettség esetében az anyák iskolai végzettségével kapcsolatban mutatható ki az erősebb összefüggés. A matematika eredmények és szülők iskolai végzettségének kapcsolatáról megállapíthatjuk, hogy a középfokú végzettséggel rendelkező apák esetében mutatható ki erősebb összefüggés a végzettség és az átlag feletti eredmények között.

Eredményeink rávilágítanak, hogy az anyák iskolai végzettsége mindhárom mérési területen meghatározóbb a gyerek kompetenciaméréseken elért eredményeire nézve. Az anyanyelv területén a középfokú végzettséggel rendelkezők esetében az apák meghatározóbb szerepe érvényesül. Legszembetünőbb az anyák általános iskolai és az átlag alatti, valamint a felsőfokú végzettség és az átlagon felüli matematika eredmények közti összefüggés. Az általános iskolai végzettséggel rendelkező szülök gyerekei alacsony arányban érnek el átlag fölötti eredményeket.

6. táblázat: Az anya iskolai végzettsége és a matematika kompetenciamérések eredményei közötti összefüggés

\begin{tabular}{lll}
\hline Anya iskolai végzettsége & \multicolumn{2}{l}{ Matematika eredmények } \\
\cline { 2 - 3 } & átlag alatt & átlag fölött \\
\hline Általános iskola & $76.9 \%$ & $23.1 \%$
\end{tabular}




\begin{tabular}{lll} 
& 12.1 & -12.1 \\
\hline Középiskola & $40.6 \%$ & $59.4 \%$ \\
& -3.0 & 3.0 \\
\hline Felsőfokú végzettség & $16.6 \%$ & $83.4 \%$ \\
& -9.4 & 9.4 \\
\hline
\end{tabular}

$\mathrm{N}=1007$, Sig.***.

\section{Összegzés}

Tanulmányunkban a romániai elemi tagozat végén sorra kerülő országos kompetenciamérések Kovászna megyei eredményeit mutattuk be. Arra kerestük a választ, hogy milyen tényezők befolyásolják a tanulók eredményeit? Kíváncsiak voltunk arra, hogy az előkészítő osztály pozitívan befolyásolja-e a mérések eredményeit. 2012-ben, amikor bevezetésre került az előkészítő osztály, a szülő eldönthette, hogy előkészítő osztályba vagy első osztályba íratja a gyerekét. Lehetőségünk adódott összehasonlítani azoknak a gyerekeknek a mérési eredményeit, akik jártak előkészítő osztályban azokkal a gyerekekkel, akik valamilyen okból kifolyólag nem jártak, s első osztályban csatlakoztak az évfolyamon járókhoz. Az óvoda és az iskola között hosszabb átmenet az iskolai kudarcok csökkentését is biztosítja, több időt hagyva az iskola teljesítményorientált munkamódjához való hozzászokásra (Mihály, 2001). Kutatásunk eredményei összhangban vannak a pedagógusok véleményével is, mely szerint jelentős előrehaladás történt az előkészítő osztály bevezetésével. A pedagógusok sikeres intézkedésnek ítélik meg a korai iskolakezdést (Barabás, 2019).

A szülők iskolai végzettségét vizsgálva megállapíthatjuk, hogy általános iskolai szinttel rendelkező apák és anyák aránya nem tér el nagymértékben egymástól. A középiskolai végzettségü apák aránya magasabb, míg az anyák nagyobb arányban rendelkeznek felsőfokú végzettséggel. A középfokú végzettség az apák, míg az általános és felsőfokú iskolai végzettsége az anyák esetében korrelál szorosabban a mérési eredményekkel. Ahol a szülők legmagasabb iskolai végzettsége az általános iskola, alacsonyabb arányban érnek el a tanulók átlagon felüli eredményeket.

Eddigi elemzésünk alapján megállapíthatjuk, hogy az előkészítő osztály és a kompetenciaméréseken elért eredmények között szignifikáns összefüggés mutatható ki: nagyobb arányban érnek el átlag fölötti eredményeket azok a tanulók, akik előkészítőben jártak, mint azok, akik nem. Ugyanakkor a szülők iskolai végzettsége és a mérési eredmények közti összefüggés vizsgálata alátámasztja, hogy a magasabb fokú iskolai végzettséggel rendelkező szülők gyerekei nagyobb arányban érnek el átlagon felüli eredményeket, mint az általános iskolai végzettséggel rendekező szülők gyerekei. A felsőfokú végzettséggel rendelkező szülők gyerekei nagyobb eséllyel kerülnek az átlag feletti kategóriába mindhárom kompetenciamérési területen.

Elemzésünk rávilágít arra, hogy a kompetenciamérések eredményeit a családi és iskolai háttér nagymértékben befolyásolja. Meggyőződésünk szerint vizsgálatunk jelzésértékkel bír és mélyebb összefüggések feltárására sarkall, ami új kutatási irányokat szabhat meg az oktatási eredményesség vizsgálatában.

\section{Irodalomjegyzék}

Andor M., Liskó I. (2000): Iskolaválasztás és mobilitás. Iskolakultúra, Budapest.

Bacskai K. (2007): Iskolai légkörvizsgálat nyolc debreceni gimnáziumban. Educatio, 2, 323-330.

Bacskai K. (2015): Iskolák a társadalom peremén. Belvedere Meridionale Kft., Szeged.

Barabás A. (2019): Visszajelzések az előkészítő osztályról, In: Boda A. (szerk.): Interdiszciplinaritás a Kárpát-medencében I. ELTE Márton Áron Szakkolégium, Budapest, 245-262.

Báthory Z. (2002): A rendszerszintű oktatási felmérések néhány tanulsága, Új Pedagógiai Szemle, 52, 31-37. 
Bourdieu, P. (1999): Gazdasági tőke, kulturális tőke, társadalmi tőke. In: Angelusz R. (szerk.): A társadalmi rétegzödés komponensei. Új Mandátum Könyvkiadó, Budapest, 156-178.

Bradley, R., Corwyn, R. (2002): Socioeconomic status and child development. Annual Review of Psychology, 371-399.

Buda A. (2011): Értékelési filozófiák és pedagógiai mérés. Debreceni Egyetem Tudományegyetemi Karok, Debrecen.

Chrappán M. (1998): A diszciplináris tárgyaktól az integrált tárgyakig. Új Pedagógiai Szemle, 48(12), 59-74.

Csapó B. (1998): Az iskolai tudás, Osiris Kiadó, Budapest.

Fehérvári A. (2016): Iskolai eredményesség és hátrányos helyzet. In: Szemerszki M. (szerk.): Hátrányos helyzet és iskolai eredményesség. Oktatáskutató és Fejlesztő Intézet, Budapest, 15-28.

Fóris-Ferenczi R. (2007): Kisebbségi oktatás Romániában felső középfokon. In. Mandel K., Papp Z. A. (szerk.).: Cammogás. Minöségkoncepciók a romániai magyar középfokú oktatásban. Soros Oktatási Központ, Csíkszereda, 45-83.

Fóris-Ferenczi R. (2008): A tervezéstöl az értékelésig. Tanterv- és értékeléselmélet. Ábel Kiadó, Kolozsvár.

Kádár E. (2016): A magyar nyelv tantárgy tartalma és oktatás a romániai oktatás szabályozási keretben, Kolozsvár [2017.04.27]

Kozma T. (2003): Kisebbségi oktatás Közép-Európában, Oktatáskutató Intézet, Budapest.

Manolescu, D., Potolea, M. (2006): Teoria si metodologia curriculumului [2018.01.04]

Melhuish, E. et al. (2008): Effects of the home learning environment and preschool center experiences upon literacy and numeracy development in early primary school. Journal of Social Issues, 64(1), 95-114.

Mullis, I. et al. (2007): PIRLS 2006 international report: IEA's progress in international reading literacy study in primary schools in 40 countries. Chestnut Hill, MA: Boston College [2018.12.06.]

Kitchen, H. et al. (2017): OECD Reviews of Evaluation and Assessment in Education: Romania 2017. [2017.10.31]

Papp Z. A. (2012): Kisebbségi magyarok oktatási részvételének értelmezési lehetőségei. Educatio, 21(1), 3-23.

Péter L. (2012): Reform és visszhangok. A közoktatási reform fogadtatása romániai magyar pedagógusok körében. Kolozsvári Egyetemi Kiadó, Kolozsvár.

Pletl R. (2012): Helyzetjelentés az erdélyi magyar diákok olvasási és szövegértési képességének színvonaláról. Ábel Kiadó, Kolozsvár.

Pusztai G. (2009): A társadalmi tőke és az iskola. Kapcsolati erőforrások hatása az iskolai pályafutásra. Új Mandátum Könyvkiadó, Budapest.

Pusztai G. (2004): Iskola és közösség-Felekezeti középiskolások az ezredfordulón. Gondolat Kiadó, Budapest.

Róbert P. (2004): Iskolai teljesítmény és társadalmi háttér nemzetközi összehasonlításban. In: Kolosi T. et al. (szerk.): Társadalmi riport. TÁRKI, Budapest.

Szántó B. (2015): A 4. osztályos tanulók anyanyelvi szövegértésének szintje a 2013/2014-es országos felmérések tükrében, http://padi.psiedu.ubbcluj.ro/pedacta/article_5_1_1.pdf [2017.11.09.]

Széll K. (2015): Iskolai eredményesség a hátrányos helyzet tükrében, EPA01551_ecucatio_2015_1_140-147.pdf [2018.04.21.] 


\section{Szerzó}

Barabás Andrea, Debreceni Egyetem, Debrecen (Magyarország). E-mail: andrea.barabas17gmail.com 